\title{
Age-dependent alteration in muscle regeneration: the critical role of tissue niche
}

\author{
Laura Barberi • Bianca Maria Scicchitano - Manuela De Rossi • Anne Bigot • \\ Stephanie Duguez $\cdot$ Aurore Wielgosik $\cdot$ Claire Stewart · Jamie McPhee • \\ Maria Conte $\cdot$ Marco Narici $\cdot$ Claudio Franceschi • Vincent Mouly • \\ Gillian Butler-Browne $\cdot$ Antonio Musarò
}

Received: 29 January 2013/ Accepted: 29 April 2013/Published online: 12 May 2013

(C) The Author(s) 2013. This article is published with open access at Springerlink.com

\begin{abstract}
Although adult skeletal muscle is composed of fully differentiated fibers, it retains the capacity to regenerate in response to injury and to modify its contractile and metabolic properties in response to changing demands. The major role in the growth, remodeling and regeneration is played by satellite cells, a quiescent population of myogenic precursor cells that reside between the basal lamina and plasmalemma and that are rapidly activated in response to appropriate stimuli. However, in
\end{abstract}

Laura Barberi and Bianca Maria Scicchitano contributed equally to this study.

L. Barberi · M. De Rossi - A. Musarò

Institute Pasteur Cenci-Bolognetti, DAHFMO-Unit of

Histology and Medical Embryology, IIM,

Sapienza University of Rome, Rome, Italy

B. M. Scicchitano

Institute of Histology and Embryology, Catholic

University School of Medicine, Rome, Italy

A. Bigot - S. Duguez - A. Wielgosik - V. Mouly ·

G. Butler-Browne

Thérapie des Maladies du Muscle Strié, Institut de Myologie UMRS 974-UPMC University, Paris 6, U974Inserm, UMR7215-CNRS, AIM, GH Pitié-Salpétrière, 47 bd de L'Hôpital, Paris cedex 13, 75651 Paris, France

\section{Stewart}

Research Institute for Sport and Exercise Sciences, School of Sport and Exercise Sciences, Liverpool John Moores University, Tom Reilly Building, Byrom Street Campus, Liverpool L3 3AF, UK pathologic conditions or during aging, the complete regenerative program can be precluded by fibrotic tissue formation and resulting in functional impairment of the skeletal muscle. Our study, along with other studies, demonstrated that although the regenerative program can also be impaired by the limited proliferative capacity of satellite cells, this limit is not reached during normal aging, and it is more likely that the restricted muscle repair program in aging is presumably due to missing signals that usually render the damaged muscle a permissive environment for regenerative activity.

\section{J. McPhee \\ Institute for Biomedical Research into Human Movement and Health Manchester Metropolitan University, \\ John Dalton Building, Chester Street, \\ Manchester M1 5GD, UK \\ M. Conte - C. Franceschi \\ Department of Experimental Diagnostic and Specialty Medicine and Interdepartmental Centre "L. Galvani" (CIG), University of Bologna, via S. Giacomo 12, 40126 Bologna, Italy \\ M. Narici \\ Division of Clinical Physiology, School of Graduate Entry to Medicine, Derby Royal Hospital, University of Nottingham, Uttoxeter Rd, Derby DE22 3DT, UK}

A. Musarò

Center for Life Nano Science@Sapienza,

Istituto Italiano di Tecnologia, Rome, Italy 
Keywords Sarcopenia - Muscle regeneration . Satellite cells · Tissue niche · Growth factors . Stem cells

\section{Introduction}

Mature skeletal muscle is composed of myofibers, which are multinucleated syncytia arising from the fusion of mononucleated precursor cells. In addition, there is a population of mononucleated muscle stem cells, known as satellite cells, that reside at the periphery of muscle fibers between the basal lamina and the sarcolemma. Historically, satellite cells were identified using electron microscopy by Mauro (1961), who reported that satellite cells might be "dormant myoblasts that failed to fuse with other myoblasts and are ready to recapitulate the embryonic development of the skeletal muscle fibers when the main multinucleate cell is damaged".

Since these early observations, it has become evident that muscle regeneration is a coordinated process in which multiple factors are sequentially activated to restore and/or preserve muscle structure and function upon injury and represents an essential homeostatic process, which guarantees the maintenance of muscle integrity and plasticity. In response to damage, fibre regeneration must be finely orchestrated between the different cellular and molecular partners, such as inflammatory, anti-inflammatory or interstitial cells or signaling pathways, to lead from degenerating fibres to a newly regenerated and functional tissue with its pool of precursors restored for future repair.

\section{The phases of muscle regeneration}

Muscle regeneration and repair occur in four interrelated and time-dependent phases: degeneration, inflammation, regeneration, and remodeling-repair (Carosio et al. 2011; Tidball and Villalta 2010) (Fig. 1a). Injury of myofibers results in rapid necrosis, due to an influx of extracellular calcium that induces proteolysis of the myofibers (Oberc and Engel 1977).

\footnotetext{
A. Musarò $(\bowtie)$

Sapienza University of Rome-Unit of Histology and

Medical Embryology, Rome, Italy

e-mail: antonio.musaro@uniroma1.it
}

The presence of necrotic fibers activates a defined inflammatory response (Fig. 1b) that is characterized by the sequential invasion of the muscle by specific inflammatory cell populations. Although neutrophils are the first inflammatory cells to arrive at the sites of lesion, macrophages are the predominant inflammatory cell type which rapidly infiltrates the injured area and several findings suggest that macrophages play a key role not only in removing tissue debris, but also in the activation of stem cell-mediated muscle repair and regeneration (St. Pierre BA and Tidball JG 1994; Arnold et al. 2007) by secreting cytokines and growth factors (Paliwal et al. 2012) (Fig. 1a). Two different classes of macrophages, known as M1 and M2, have been described and characterized (Mantovani et al. 2004) (Fig. 1a). M1 macrophages are the first macrophages to invade injured muscle following acute damage, where they produce proinflammatory cytokines and may cause further tissue damage through the release of nitric oxide (Nguyen and Tidball 2003; St. Pierre and Tidball 1994; Krippendorf and Riley 1993). M1 macrophages also exert a pro-proliferative effect on other types of cells, including activated satellite cells, referred to as myoblasts in this activated state (Arnold et al. 2007; Bencze et al. 2012; Paliwal et al. 2012).

M2 macrophages, which progressively replace M1 macrophages at sites of injury, have been shown to play a major role in promoting growth and regeneration. In contrast to M1, M2 cells tune the inflammatory response, scavenge debris and promote angiogenesis, tissue remodeling and repair (St. Pierre and Tidball 1994; Krippendorf and Riley 1993; Tidball and Wehling-Henricks 2007): their absence causes a delay in muscle growth and inhibits muscle differentiation and regeneration. Thus, this transition in macrophage phenotype is an essential component of muscle regeneration in vivo following acute or chronic muscle damage (Tidball and Villalta 2010).

This initial inflammatory response is followed by a phase of active regeneration (Fig. 1a), characterized by satellite cell activation, and initiation of regenerating fibers, which can be morphologically identified in the mouse by the presence of characteristic central nuclei (Karpati and Molnar 2008), which are the result of the differentiation of activated satellite cells (Zammit et al. 2002; Tajbakhsh 2009).

The final phases of myofibre regeneration include: a period during which maturation of contractile apparatus 


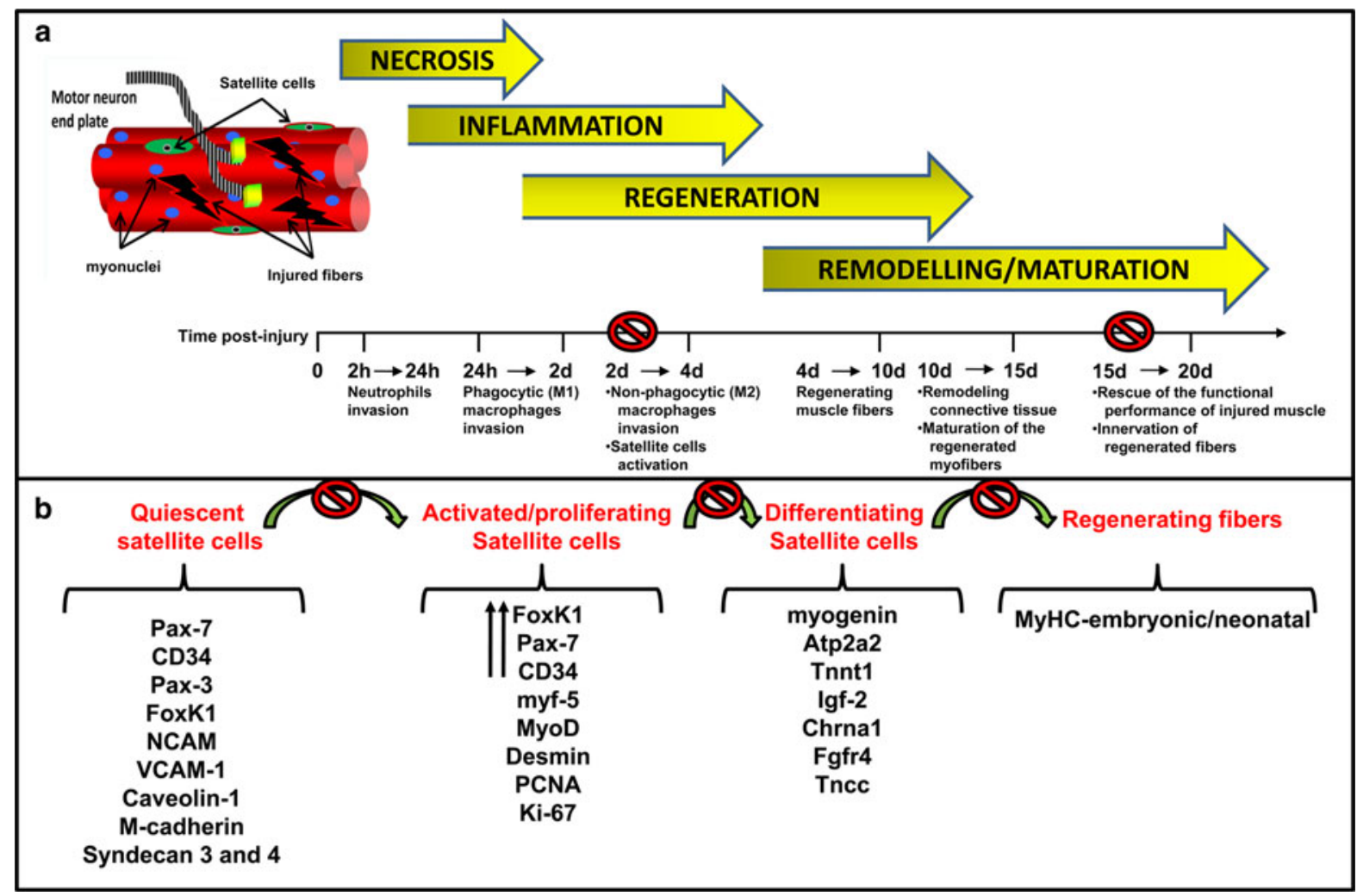

Fig. 1 Schematic model depicting muscle regeneration. (a) Schematic representation of the four interrelated and timedependent phases underlying muscle regeneration. The relevant biological responses, activated after cardiotoxin (CTX)

occurs, where destruction has been extensive, innervations is re-established, remodeling of extracellular matrix is initiated (impacting on scar tissue formation (Fig. 1a) and recovery of the functional performance of the injured muscle occurs (Goetsch et al. 2003).

\section{The cellular basis of muscle regeneration: the role of satellite cells and non-muscle stem cells on muscle regeneration}

The importance of satellite cells in muscle repair promoted the characterization of molecular markers selectively expressed by satellite cells, but not by muscle fibers. It has been reported that Pax3, Pax7, M-cadherin, FoxK, NCAM, syndecans 3 and 4, CD34 and VCAM-1 are all markers expressed by quiescent satellite cells (Fig. 1b) (Carosio et al. 2011; Hawke and Garry 2001; Zammit 2008; Buckingham 2007). Once activated, satellite cells up-regulate expression injection, are indicated. (b) Schematic model outlining the relevant markers expressed by satellite cells during the different stages of regeneration. (h: hours; d: days). ( stages of muscle regeneration that could be impaired in muscle aging

of c-Met, Pax-7 and M-cadherin and also activate the expression of factors involved in the specification of the myogenic program such as myf-5 and MyoD (Fig. 1b). The activated satellite cells proliferate as indicated by the expression of transcription factors involved in cell cycle progression (Fig. 1b) and by the incorporation of BrdU and $[3 \mathrm{H}]$ thymidine (Yin et al. 2013). Ultimately the committed satellite cells will either fuse with each other, or to the existing fibers, to form new muscle fibers, which are characterized by their small size and in rodents by the presence of characteristic central nuclei. The transition from cell proliferation to differentiation involves myogenic factor as MyoD (Halevy et al. 1995) and the exit from the cell cycle by upregulation of factors such as p21 (Guo et al. 1995) or p57 as demonstrated in vitro (Reynaud et al. 2000; Bigot et al. 2008) and later the activation of other muscle specific protein genes, including the embryonic and neonatal isoforms of the myosin heavy chain (MyHC) (Carosio et al. 2011) 
(Fig. 1b). The kinetics of muscle regeneration has also been investigated in vivo using implantation of human satellite cells into the regenerating tibialis anterior (TA) of immunodeficient mice. Satellite cell death at implantation varies depending on the experimental conditions and can reach over $90 \%$ (Beauchamp et al. 1999; Skuk and Tremblay 2003); implanted human cells proliferate during a relatively limited period of time and differentiate as early as 3-5 days posttransplantation, a time-point after which there is no more proliferation and no more dispersion of satellite cells within the regenerating muscle (Riederer et al. 2012).

Several studies have also raised the possibility that satellite cells are a heterogeneous mixture of stem cells and committed myogenic progenitors (Schultz and Lipton 1982; Grounds and McGeachie 1987; Moss and Leblond 1971; Schultz 1996). This hypothesis was supported by radioisotope labeling experiments, demonstrating that rat satellite cells are a mixture of $80 \%$ fast-cycling cells and $20 \%$ slowcycling "reserve cells" (Schultz 1996). Asymmetric division of stem cells in the satellite cell niche is a mechanism proposed for generating these two different populations (Kuang et al. 2007). In particular, Pax7-positive satellite cells that lack Myf5 expression have a "stem-like" phenotype within the satellite cell population. In contrast, Pax7-positive satellite cells expressing Myf5 were more committed to a muscle fate (Kuang et al. 2007). It has also been proposed that other "non-muscle" stem cell populations can participate in muscle regeneration and in some way contribute to maintaining the pool of satellite cells. These stem cell populations could either reside within muscle, or be recruited via the circulation in response to homing signals emanating from the injured skeletal muscle. These populations include endothelial-associated cells (De Angelis et al. 1999), interstitial cells (Kuang et al. 2006; Polesskaya et al. 2003; Tamaki et al. 2002) and bone marrow-derived stem cells (Asakura et al. 2002; Gussoni et al. 1999). However, these cells rarely participate to the formation of muscle fibres (Ferrari et al. 2001, Partridge 2004).

Nevertheless, even though skeletal muscle possesses a stem cell compartment, which decreases with age in rat, mice and humans (Snow 1977; Collins et al. 2007; Sajko et al. 2004; Verdijk et al. 2007; Renault et al. 2002; Kadi et al. 2004; Chakkalakal et al. 2012) it is not sufficient to explain why the aged muscle presents such a diminished efficiency to regenerate. Either the potency of the resident muscle stem cells drastically decreases during aging or perhaps the senescent muscle is a prohibitive environment for stem cell activation and function.

\section{The limit in proliferation of satellite cells}

Once activated, a minority of cells will restore the satellite cell compartment through an asymmetric division (Conboy and Rando 2002; Tajbakhsh 2009), while the majority will proliferate extensively before entering terminal differentiation to replace the damaged muscle fibres.

Telomere shortening during proliferation may contribute to the inability of satellite cells to perpetually repair muscle during aging. Human satellite cells, like most somatic cells of the body, lack telomerase expression after birth, and their telomeres will shorten at each cell division until they reach a critical length which triggers proliferative arrest or senescence (Decary et al. 1997; Di Donna et al. 2003). Studies conducted in vitro showed that human satellite cells reach proliferative arrest with up to 7-9 $\mathrm{kb}$ of intact telomere length, while fibroblasts will reach proliferative arrest with $6 \mathrm{~kb}$. This discrepancy is due to the triggering of another pathway that blocks the cell cycle, at least in vitro. This pathway is stress induced and involves the upregulation of p16, which binds cdk4 and prevents this kinase from enabling cell cycle entry, as demonstrated by the requirement for inactivating both the p16 pathway and telomere shortening to immortalize human myoblasts (Zhu et al. 2007, Mamchaoui et al. 2011). Although it is not known whether p16 can also trigger proliferative arrest of activated satellite cells in vivo, the p16 pathway can be prematurely activated in dystrophic conditions such as myotonic dystrophy type 1 (DM1) where it triggers premature proliferative arrest of myoblasts at least in vitro (Bigot et al. 2009). Proliferative arrest is probably never reached in control human subjects, but can be a limiting factor in situations where repeated cycles of degeneration/regeneration occur, such as muscular dystrophies, as shown by reduced telomere lengths in cells derived from models of these conditions (Decary et al. 2000). Less is known regarding the limit in proliferation of murine myoblasts. Mouse myoblasts express telomerase, but their proliferation is 
still limited, probably by the p16 pathway, since mouse myoblasts can be immortalized by the overexpression of cdk4 that traps p16, rendering it inactive (DouillardGuilloux et al. 2009).

\section{Satellite cells display a delayed response to activating stimuli and show a reduced proliferative response to their sub-optimal environment}

To understand if proliferative aging could induce modifications in the intrinsic properties of human myoblasts, as approach to senescence does in vitro (Bigot et al. 2008), we have monitored the proliferative capacity of myoblasts isolated from young and old donors. As shown in Fig. 2, satellite cells isolated from old adults were able to proliferate and to express specific markers of activated and proliferating satellite cells, such as desmin, Pax7, Ki67, and MyoD.

We compared the proliferative capacity of satellite cells from five young donors (age range 15-24 yearold) to that of 10 old donors (age range 68-80 yearold) separated in two groups : five old sedentary and five old active based on their examination by clinicians and on a questionnaire on the lifestyle of the subjects. In order to stimulate and maintain the cultures proliferating for as long as possible, we cultured the cells in the presence of $20 \%$ of fetal calf serum. The mean number of divisions made by each population, calculated using the formula $\log (n / N) / \log 2$ where $\mathrm{n}$ is the number of cells counted at each passage and $N$ the number of cells plated initially, was determined as a function of time in culture. The lifespan curves resulting from these analyses are shown on Fig. 3. The inter-individual differences between the life spans within a group appear at least as important as the differences between the groups. We also calculated the mean number of division reached by the cultures in each group when they were senescent, as defined by the absence of any division during 3 weeks of refeeding. No statistically significant difference was observed between the maximum number of division (PDL for population doubling level) in the three groups. In order to determine the potential activation of the p16 pathway in the cultures derived from young and old subjects, we measured by qPCR the mRNA level of p16 (Fig. 4a) and the telomere length (Fig. 4b) at the beginning of the lifespan and that reached at senescence for each culture, and no difference was detected between young and old groups. In conclusion of these experiments, cultures derived from old active or sedentary subjects do not show any difference in their proliferative capacity, nor do they differ from those derived from young donors.

However, when cells were cultured in presence of $15 \%$ of autologous or heterologous sera-which may represent more physiological conditions-we observed a significant difference in the rate of proliferation when old-derived satellite cells were compared with young-derived satellite cells. In particular, the proliferative capacity of the muscle cell cultures was estimated from the cells incorporating BrdU. For this experiment, young- and old-derived satellite cells were plated at the same density and immunofluorescence analyses revealed that the percentage of BrdU-positive cells was reduced in cultures of old-derived satellite cells when cultured in autologous (homochronic) as compared to heterologous (heterochronic from young donors), or to young satellite cells (Fig. 5). These data support the evidence that during aging, satellite cells display a delayed response to activating stimuli and show a reduced proliferative response to their environment (Schultz and Lipton 1982; Conboy et al. 2003) when this environment is sub-optimal.

\section{The impaired satellite cells behaviour in sarcopenia might be mediated by altered p53 expression/ activity}

Regenerative potential decline in skeletal muscle with aging could also depend on the activation in satellite cells of p53 pathway. The tumor suppressor p53 is activated by different stress signals, such as DNA damage, leading to cell cycle arrest, apoptosis but also telomere shortening driven senescence. The exact function of p53 in skeletal muscle remains to be clearly defined, although a recent study demonstrates that p53 activation promotes atrophy in aging muscle, suggesting a pivotal role in the homeostasis of satellite cells (Schwarzkopf et al. 2008). In agreement to these findings, we observed, by real time RT-PCR, an increase in the expression levels of p53 in myoblasts derived from old (age: $73.37 \pm 2.66$ year-old) subjects with respect to young (age: $21.6 \pm 2.23$ year- 

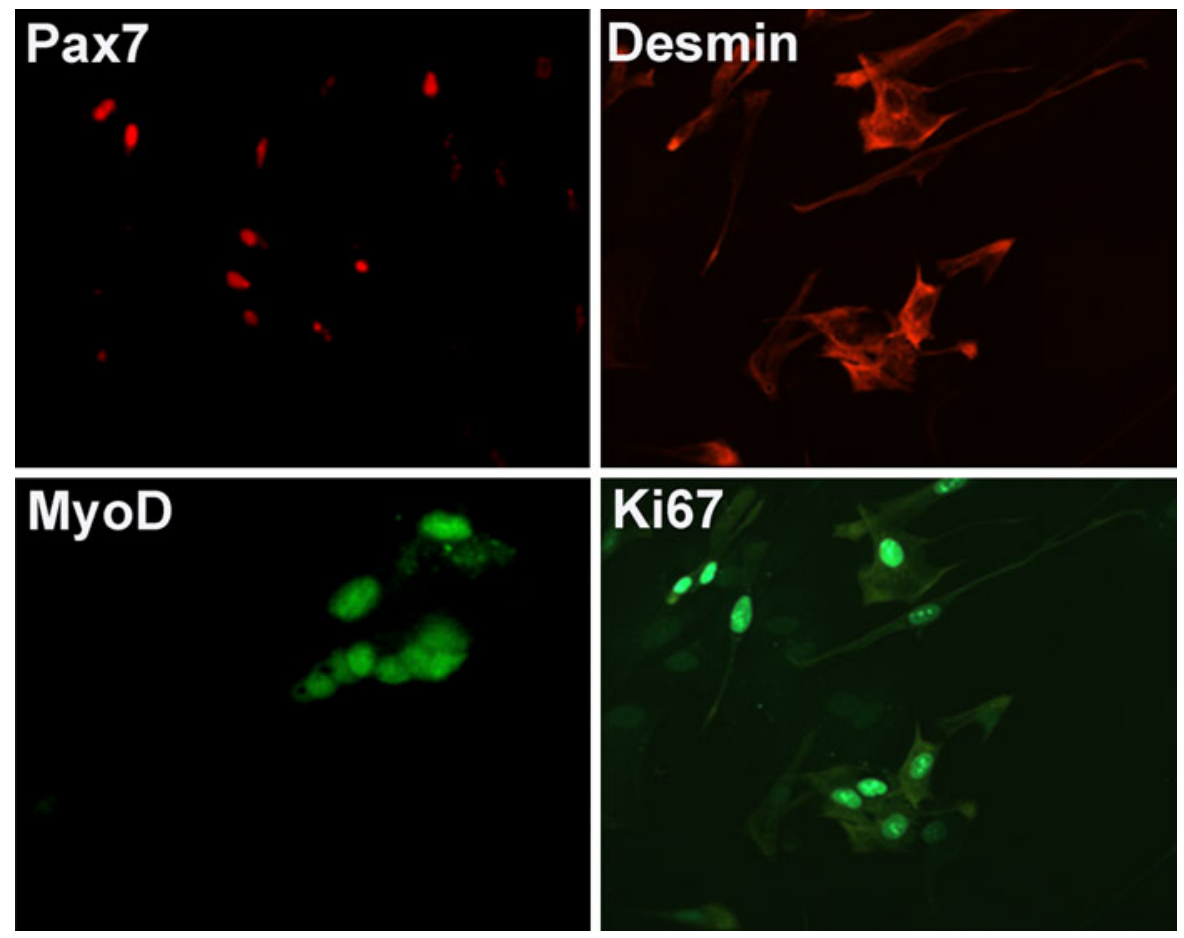

Fig. 2 Immunofluorescence analysis showing that aged satellite cells, in culture, express specific markers of activated and proliferating satellite cells, such as Pax7, desmin, MyoD, and Ki67

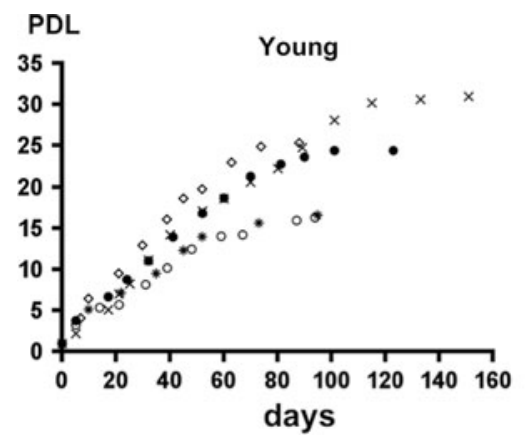

Fig. 3 Proliferative capacity of human muscle precursor cells (myoblasts) isolated from three groups of subjects (young, old sedentary and old active). The proliferative lifespan was

old). This result was also mirrored by the expression of a p53 downstream gene, p21 that appeared to be expressed at a higher level in older myoblasts compared to those derived from younger subjects (Fig. 6). Although telomere length, which can trigger the p53 pathway, do not seem to be statistically different between cultures of satellite cells from young and old subjects, other signals may be involved.

\section{Human satellite cells fail to differentiate when cultured in isochronic conditions}

We then analysed the ability of satellite cells derived from old subjects to differentiate when cultured in presence of either heterologous/heterochronic (from young donors) or autologous serum. Immunofluorescence analysis for the expression of MyHC revealed that aged satellite cells 


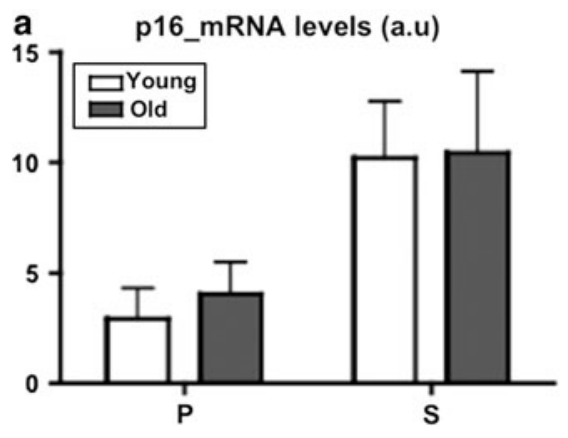

Fig. 4 p16 mRNA expression (a) and Telomere length (b) were measured by qRT-PCR and qPCR respectively in proliferative myoblasts at the beginning of their lifespan $(\mathrm{P})$ and

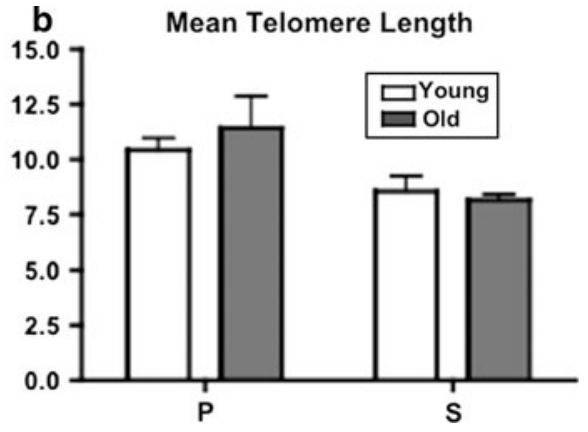

in senescence myoblasts (S). Values are mean \pm standard deviation, $n=5$ and 10 for young and old respectively
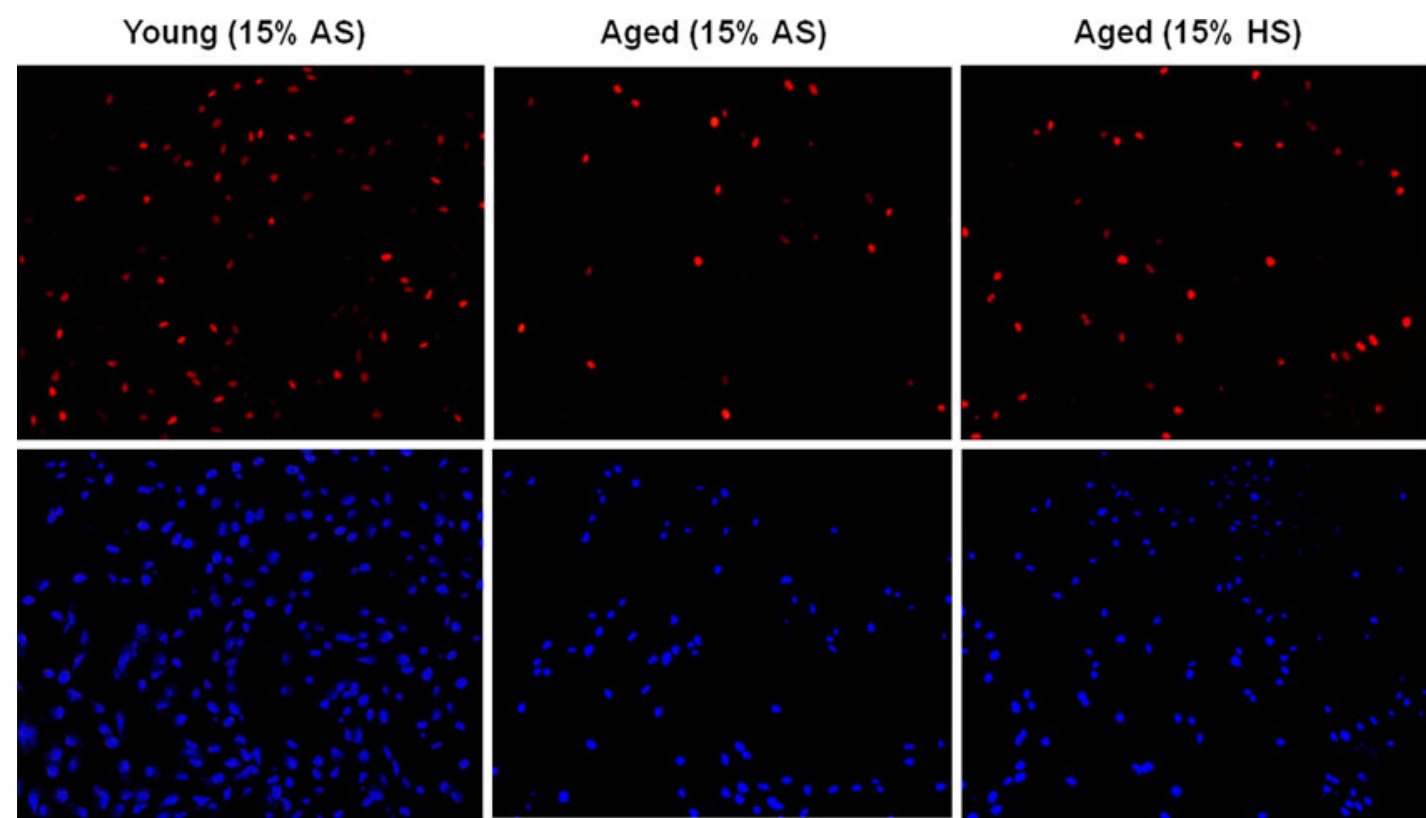

BrdU

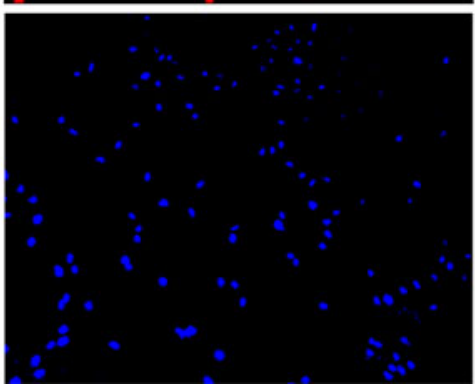

Hoechst

Fig. 5 Proliferation of aged satellite cells is impinged in autologous culture conditions. Immunofluorescence analysis for BrdU incorporation in satellite cells obtained from young $(30.3 \pm 1.8$ year-old $)$ and old $(83.3 \pm 6.3$ year-old $)$ subjects, cultured in either autologous serum (AS) or heterologous serum (HS). Old-derived satellite cells showed a $21.3 \%$ of BrdUpositive cells when cultured in autologous (homochronic) serum (middle panel), whereas old-derived satellite cells showed a

did not display major defect in the propensity to fuse when differentiated under standard conditions, namely in DMEM supplemented with $5 \%$ horse serum (data not shown). Of note, we observed that autologous serum (isochronic culture conditions) dramatically reduced muscle differentiation (Fig. 7), which was partially rescued when aged satellite cells were differentiated in
$32.5 \%$ of BrdU-positive cells when cultured in heterologous (heterochronic from young donors) (right panel). Youngderived satellite cells showed a $51 \%$ of BrdU-positive cells (left panel). No major differences in the percentage of BrdUpositive cells were observed when young-derived satellite cells were cultured in either autologous (homochronic) or heterologous (heterochronic from old donors) serum. Bottom panels show Hoechst nuclear staining

heterologous/heterochronic serum (from young donors) (Fig. 7).

Of note, Beccafico et al. (2011) also demonstrated that aged satellite cells show altered expression levels of S100B, RAGE, and Pax7 and a reduced ability to secrete bFGF and S100B among other factors, which appear to be responsible for the defective proliferation 

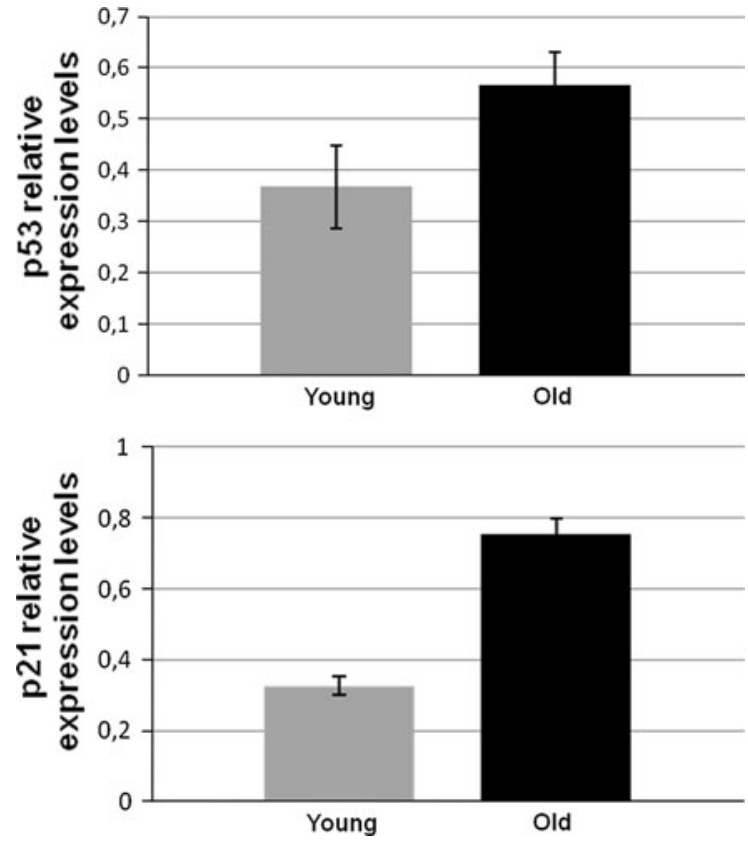

Fig. 6 p53 and p21 expression is increased in aged myoblasts. Real time PCR for the expression of $\mathrm{p} 53$ and $\mathrm{p} 21$ on myoblasts obtained from young (21.6 \pm 2.23 year-old) and old $(73.37 \pm 2.66$ year-old) subjects. Data are represented as average \pm SEM. (p53: $p=0.02 ; \mathrm{p} 21: p=0.03)$

and differentiation. Indeed, the proliferation and differentiation defects was rescued by cultivation of aged satellite cells in young satellite cells conditioned media which contain bFGF and S100B among others (Beccafico et al. 2011). It is plausible that the changes in these intrinsic factors reflect changes in the aged satellite cells microenvironment or alterations of the cellular machinery regulating the expression levels of those factors.

\section{Sarcopenia interferes with muscle regeneration: an overview}

What are the molecular and cellular mechanisms that limit the senescent muscle to sustain an efficient regenerative process?

The important seminal studies of Bruce Carlson clearly indicated that skeletal muscle regeneration is less successful in old than in young individuals (Carlson 1968; Carlson 1972; Carlson 1973; Carlson 1995). Several factors might be involved: (1) reduced number and altered proliferative potential of satellite cells (Schultz and Lipton 1982; Gibson and Schultz 1983; McGeachie and Grounds 1995), (2) telomere shortening in satellite cells (Renault et al. 2000), (3) reduced innervations of senescent muscle (Larsson 1982; Larsson and Ansved 1995), (4) increased fibrotic tissue (Marshall et al. 1989), (5) altered expression and concentration of systemic, as well as local growth factors and cytokines (Barton-Davis et al. 1998; Yablonka-Reuveni et al. 1999; Chakravarthy et al. 2000; Grounds 2002; Cevenini et al. 2010), (6) activation of apoptotic pathways (Fulle et al. 2012).

Different studies have reported divergent results concerning satellite cells and ageing in mouse ranging from a marked decline, to little change, to a relative
Young $(5 \%$ AS)
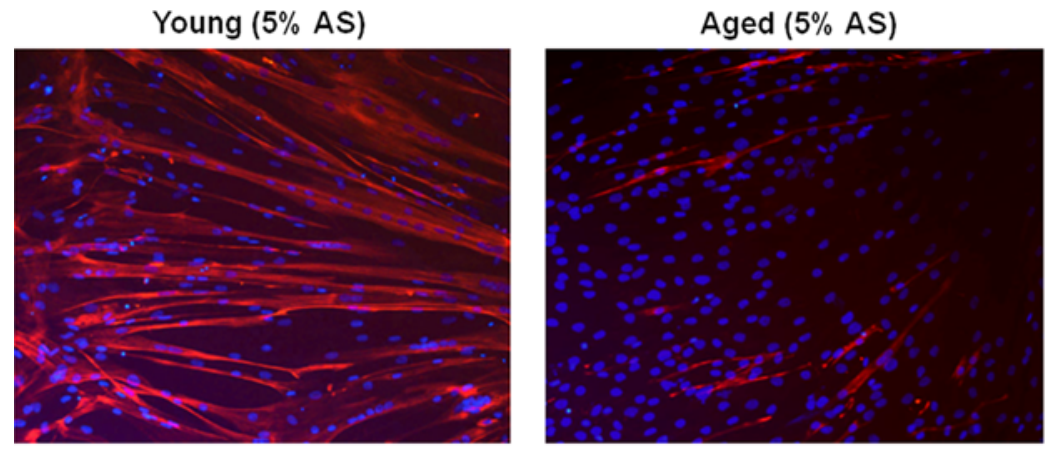

Aged (5\% HS)

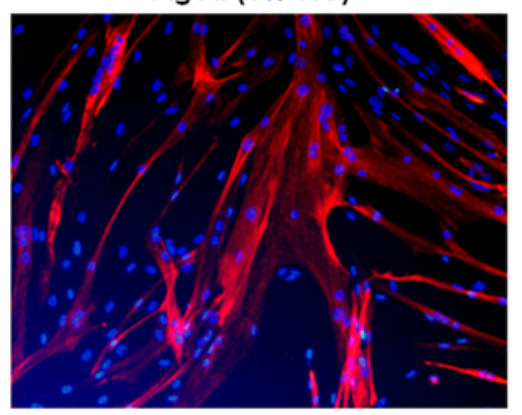

MyHC

Fig. 7 Differentiation of aged satellite cells is compromised in autologous culture conditions. Immunofluorescence analysis for MyHC expression. Muscle differentiation was evaluated analysing the expression of $\mathrm{MyHC}$, which resulted dramatically reduced in aged satellite cells cultured in autologous serum (5\% AS) and partially recovered in satellite cells cultured in heterologous serum (5 \% HS). Nuclei (blue) were stained with Hoechst 
and absolute increase (reviewed in Brack and Rando 2007) (Snow 1977; Gibson and Schultz 1983; Conboy et al. 2003; Sajko et al. 2004; Brack et al. 2005; Shefer et al. 2006). However, a decline in the number of cells expressing satellite cell markers or in a satellite cell position seems to be the general tendency in humans (Renault et al. 2002; Foulstone et al. 2003a, b; Foulstone et al. 2004). Moreover, the decline in satellite cells number seems to be more robust in the fast-twitch extensor digitorum longus (EDL) rat muscle compared to the slow-twitch soleus rat muscle (Shefer et al. 2006), in accordance with the preferential loss and atrophy of fast-twitch fibers in sarcopenia. Although the number of satellite cells appears to decline with an increasing age, the expression levels of the muscle regulatory factors (MRF), namely MyoD, myf-5 and myogenin, appear to be upregulated, at mRNA and protein level, in senescent muscle (Snijders et al. 2009; Musaro et al. 1995; Edstrom and Ulfhake 2005; Kim et al. 2005; Kosek et al. 2006; Raue et al. 2006). Of note, in rodent muscle, the magnitude of upregulation of MRF mRNA expression appears to be proportional to the degree of sarcopenia (Edstrom and Ulfhake 2005). It is conceivable that these changes might operate as a compensatory mechanism. However, we can speculate that satellite cells fail to differentiate, or myonuclei turn up the MRFs in an attempt to counteract atrophy. This can be counteracted by exercise which has been described to increase the number of satellite cells (Kadi et al. 1999, Walker et al. 2012) but this number will also decline with age even in athletes. Although no study has so far evaluated the number of satellite cells in master athletes, most of the studies on medium-term (8-12 weeks) resistance training in older individuals show an increase in satellite cell content (Mackey et al. 2007; Olsen et al. 2006; Roth et al. 2001; Verdijk et al. 2009; Verney et al. 2008). Thus, the increase in satellite cell content represents a physiological response to resistance exercise, preparing the muscle for adaptation and for the generation of new myonuclei to facilitate muscle fiber hypertrophy (Snijders et al. 2009).

Nevertheless, even if sarcopenia is associated with a decline in the number of satellite cells, the remaining resident satellite cells should be sufficient to activate and sustain an adequate regenerative mechanism. Indeed, it has been demonstrated that satellite cells maintain their potential to respond to growth promoting cues, undergo differentiation, fuse into myotubes and give rise to reserve cells throughout life, suggesting that impaired regeneration might be inflicted by the aging environment and not necessarily due to inherent changes in the cells themselves (Shefer et al. 2006). This has been confirmed in humans where satellite cells isolated from donors of varying age show an initial decline of their proliferative capacity, which then stabilizes in adults of all ages, with no statistical difference between young adults and elderly subjects (Decary et al. 1997, see Fig. 3). Thus, one of the major questions concerning the influence of aging on muscle regeneration is whether the reduction in regenerative capacity is intrinsic to the muscle or whether it is a function of the environment in which the muscle is regenerating (Carlson 2003).

Heterochronic experiments have demonstrated that old muscle successfully regenerates when transplanted in a young animal, whereas the regeneration of young muscle transplanted in an old host is impaired (Carlson and Faulkner 1989; Carlson et al. 2001). This hypothesis has been clearly validated by parabiotic experiments, the union of two organisms that share the circulatory system, demonstrating the rejuvenation of aged progenitor cells by exposure to a young systemic environment (Conboy et al. 2005). These results emphasize the importance of the environment, which is created by circulating factors, but also by the local secretome of factors secreted by the cells, such as satellite cells, the newly differentiating fibers, as well as by the inflammatory context of the early steps of muscle regeneration (Le Bihan et al. 2012). As an example, we have shown that the presence of pro- or anti-inflammatory macrophages will change the dynamics of muscle regeneration (Bencze et al. 2012), and we show in this report the effect of autologous versus heterologous and heterochronic serum on differentiation. In addition, when skeletal muscle biopsies from young and old males and females were analysed for Insulin-like growth factorI (IGF-I), IL-6 and TNF-alpha protein levels, we ascertained that males had higher local levels of all three factors (IGF-I, IL-6 and TNF-alpha) compared with females, regardless of age (data not shown). However, for TNF-alpha alone, in both males and females, age culminated in an increase in the local skeletal muscle milieu of TNF-alpha (Fig. 8a), a cytokine known to induce murine myoblast apoptosis (Stewart et al. 2004) and to block human muscle cell 

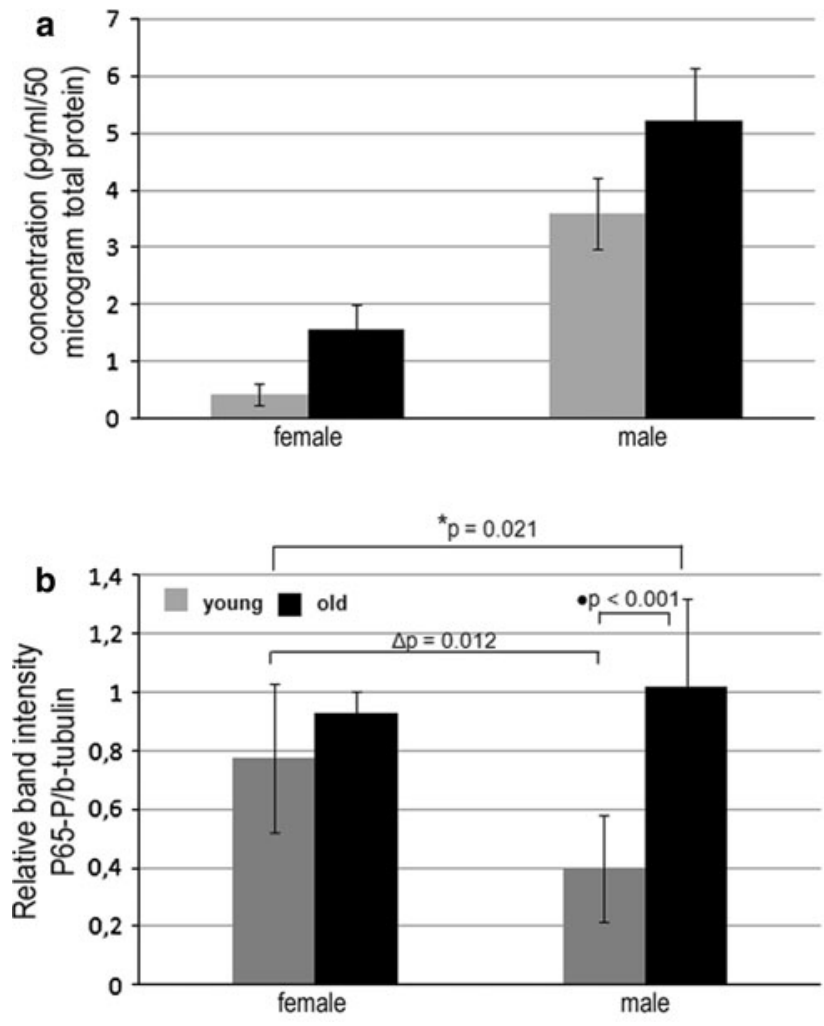

Fig. $8 \mathrm{TNF} \alpha$ levels and NFkB expression increase in the muscle of old subjects. (a) Elisa assay to evaluate the concentration of TNF $\alpha$ in muscles of young and old females and males indicated. Data are represented as average \pm SEM. $n=12$ old females, $n=17$ young females, $n=15$ old males, $n=12$ young males. (b) Left panel: western blot quantification of phosphorylated active forms of NF- $\mathrm{kB}$ p65 subunit (P-p65).

differentiation (Foulstone et al. 2004). The increase of TNF-alpha with aging and inactivity was also associated with a significant increase in $\mathrm{NF \kappa B}$ expression in the muscle of male, but not of female, (Fig. 8b). As it is well known, $\mathrm{NF \kappa B}$ is a transcription factor that controls the gene expression of numerous inflammatory proteins, such as TNF-alpha. In addition to a potential role for TNF-alpha in regulating muscle mass with inactivity, Notch, Wnt, IGF-I, and myostatin may modulate the pathological niche. Notch signaling is one of the major pathways that regulates the activation and expansion of the satellite cell lineage during embryogenesis (Vasyutina et al. 2007) and cell fate, i.e. undifferentiated progenitor versus differentiated progeny, in the adult (Conboy and Rando 2002). The decline of Notch signaling with age

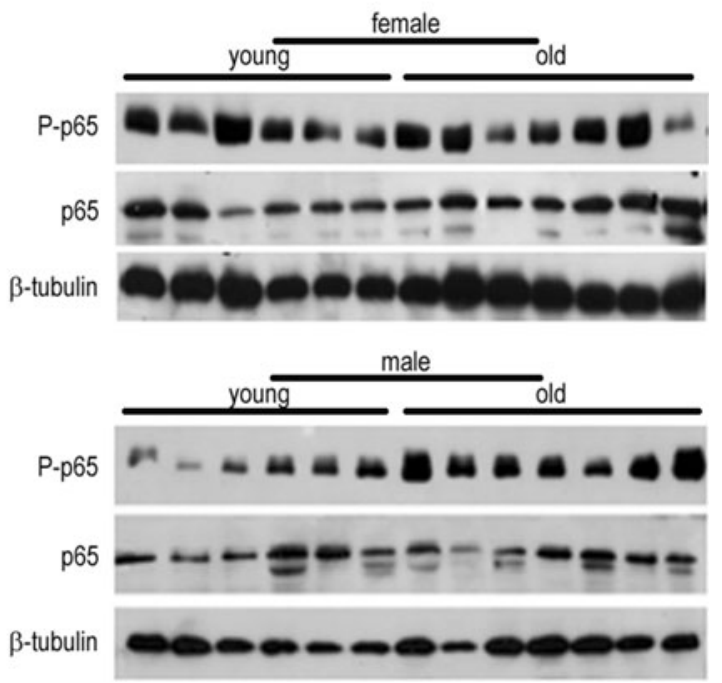

Subjects were categorized by age (young, $<40$ years; and old, $>70$ years) and by gender. Quantification was performed using ImageJ software and normalized to $\beta$-tubulin used as loading controls. ${ }^{*} p<0.021$, one-way ANOVA test; $\bullet p<0.001$ and $\Delta p=0.012$, Student' $t$ test. Right panel shows representative western blot analysis for P-p65 and total p65 in female and male of different age

is thought to be one of the causes of the decrease in the activity of satellite cells, and potentially the decreased regenerative potential of satellite cells in aged mice (Conboy et al. 2005). Indeed forced activation of Notch signaling in injured muscle of aged mice restores the regenerative potential of that tissue (Conboy et al. 2003). In addition, the temporal balance between Notch and Wnt signaling orchestrates the precise progression of muscle precursor cells along the myogenic lineage pathway, during postnatal myogenesis (Conboy et al. 2003). Nevertheless, Wnt signaling must be finely modulated, since a persistence of Wnt signaling, as for example is observed in aged mice, can be associated with an increase in tissue fibrosis (Chilosi et al. 2003; Brack et al. 2007; Jiang et al. 2006). 
Among the different growth factors, IGF-I has been implicated in many anabolic pathways in skeletal muscle and has been shown to play a central role during muscle regeneration (Scicchitano et al. 2009; Foulstone et al. 2004; Crown et al. 2000). Unlike other growth factors IGF-I also stimulates myogenic differentiation and generates a pronounced hypertrophy of the muscle cells in vivo and in vitro (Musarò and Rosenthal 1999; Musarò et al. 1999; Musarò et al. 2001, Jacquemin et al. 2004), suggesting that this growth factor can regulate both proliferative and differentiation responses in muscle cells, the two stages which guarantee the achievement of the regenerative program. IGF-I has been shown not only to provoke hypertrophy, but can also recruit additional satellite cells to the hypertrophic fibre by provoking the release of IL13, thus ensuring a functional nuclear domain to these fibres (Jacquemin et al. 2007). Analyses of transgenic mice expressing different IGF-I isoforms have provided insight into the role of local IGF-I signaling in the physiology of striated muscle (see also Sandri et al. 2013 this issue). By controlling the transcription of IGF-I transgenes with different promoters it has been possible to characterize the role of the local and/or circulating form of IGF-I on muscle cell and tissue function. Results from different studies suggest that after muscle injury, the IGF-1Eb isoforms are expressed first, followed by an increase in the expression of the IGF-1Ea isoform; the peak of IGF-IEb transcripts coincides with satellite cell and myoblast proliferation, whereas the peak of IGF-IEa mRNA is correlated with the maturation of the myofibers (Shavlakadze et al. 2005). We have also demonstrated that the local form of IGF-I (mIGF-I) promotes an increased recruitment of proliferating bone marrow cells to injured transgenic muscles and modulates the inflammatory response, accelerating the functional rescue of injured skeletal muscle (Musarò et al. 2004; Pelosi et al. 2007).

Other factors that have been shown to modulate muscle regeneration belong to the family of transforming growth factor- $\beta$ (TGF $\beta$ s) which are known to suppress myogenic differentiation. Among these, myostatin is a negative regulator of skeletal muscle growth (Dominique and Gerard 2006; McPherron et al. 1997; Kambadur et al. 1997; Schuelke et al. 2004; Carnac et al. 2006). Myostatin potentially antagonizes muscle regeneration by limiting satellite cell proliferation and differentiation. Injured muscles lacking functional myostatin, exhibit improved regeneration and reduced fibrosis, while over expression of myostatin leads to reduced muscle size and increased wasting (Wagner 2005; Reisz-Porszasz et al. 2003; Jespersen et al. 2006). However, the consequences of these complex signaling interactions is not always straight-forward, and even though inhibition of myostatin leads to muscle hypertrophy, whether it also leads to an increase in specific force is highly debated (Schirwis et al. 2012; Ploquin et al. 2012; Mendias et al. 2011; Mendias et al. 2006; Personius et al. 2010), and single-target pharmacological or genetic intervention may result in adverse effects that could result in a different outcome than initially thought. It has been documented that blocking the effects of myostatin, not only renders the increased muscle mass more susceptible to contraction-induced injury, but more recently, using murine models, it has been shown that myostatin deficiency resulted in an impaired structure and function of tendon tissues (Mendias et al. 2008).

Recent studies also suggest that apoptosis might be another mechanism involved in sarcopenia (Fulle et al. 2012; Marzetti et al. 2012). Compared with young animals, a significant increase in muscle cell apoptosis coupled with a decrease in gastrocnemius muscles weight and muscle fiber cross-sectional area, of both fast and slow fiber types, was noted in old mice (Kovacheva et al. 2010; Sinha-Hikim et al. 2013a). Oxidative stress (Marzetti et al. 2008), chronic inflammation (Phillips and Leeuwenburgh 2005), and impaired insulin sensitivity (Turpin et al. 2006) seems to be potential candidates for the activation of myonuclear apoptosis at old age.

\section{Oxidative stress and sarcopenia}

Emerging evidences have assigned to oxidative stress a critical role in muscle homeostasis and in the physiopathology of skeletal muscle (Musarò et al. 2010; Fulle et al. 2005). There are evidences demonstrating that ROS are not merely toxic species but alsowithin certain concentrations-useful signaling molecules regulating physiological processes (Musarò et al. 2010). It is clear that transiently increased levels of oxidative stress might reflect a potentially health promoting process, while an uncontrolled accumulation of oxidative stress might have pathological implication. The first scientist who hypothesized a 
correlation between oxidative damage and senescence was Harman in 1956 (Harman 1956). However, how such an oxidative insult plays a direct role in the disease-related decrease of muscle performance and mass (atrophy) remains largely unknown. In addition, the discrepancy among different studies has further complicated the achievement of a conclusive link between altered balance of ROS generation and atrophy-associated diseases. Nevertheless, recent reports contribute to clarify how the disruption of the delicate balance between ROS production and antioxidant defense may activates a cascade of events, leading to muscle atrophy and wasting (Musarò et al. 2010; Dobrowolny et al. 2008). Evidence in support of this theory comes from observations that: (1) oxidative damage to macromolecules accumulates with normal aging, (2) variations in life span among different species correlate inversely with rates of mitochondrial generation of oxidant species, and (3) experimental interventions which extend life span result in reductions in oxidative damage (Sohal and Weindruch 1996).

Superoxide dismutase (SOD) enzymes are antioxidants that protect cells from oxidative stress by catalyzing the dismutation of superoxide to oxygen and hydrogen peroxide. It has been previously reported that SOD2 knockout mice exhibit reduced electron transport chain components and lipid accumulation in skeletal muscle (Li et al. 1995; Esposito et al. 1999). Additionally, SOD2 knockout mice display a dilated cardiomyopathy (Li et al. 1995; Lebovitz et al. 1996). These studies, however, did not explicitly address the importance of SOD2 function in the muscle for whole organism vitality and longevity. Martin and colleagues extended these previous reports demonstrating that the selective knockdown of SOD2 in the musculature of Drosophila is sufficient to shorten life span and to accelerate locomotor declines (Martin et al. 2009). Flies with knockdown of SOD2 in muscle exhibit mitochondrial pathology, reduced ATP content, and elevated caspase activity, suggesting that the consequences of SOD2 loss in this tissue extend to the viability of the organism as a whole. Another study, by Zhang et al. (2009) suggested other interpretations about the role of oxidative stress and longevity. It has been previously reported that the single knock out in two mitochondrial-localized antioxidant enzymes, $\mathrm{Mn}$ superoxide dismutase (MnSOD) and glutathione peroxidase-1 (Gpx-1) displays altered mitochondrial function, increased sensitivity to apoptosis, increased cancer incidence, and susceptibility to oxidative stress, without significantly altering the life span (Williams et al. 1998; Esposito et al. 2000; Van Remmen et al. 2003; Lee et al. 2006). Because the antioxidant defense system is a complex and integrated system, it is possible that deficiency of a single antioxidant enzyme may not compromise the system to a magnitude sufficient to alter longevity. Of note, mice deficient in both Mn superoxide dismutase and glutathione peroxidase- 1 have increased oxidative damage and a greater incidence of pathology but no reduction in longevity (Zhang et al. 2009). Moreover, other studies provided direct evidence that age-associated increase in oxidative stress plays a crucial role in neuromuscular junction (NMJ) degeneration and progression of sarcopenia (Jang and Van Remmen, 2011). Homozygous deletion of SOD1 leads to age-dependent muscle atrophy with alterations in NMJs that are similar to normal aging muscle but with a more frequent and earlier occurrence (Jang et al. 2010; Muller et al. 2006).

The complex situation between oxidative stress and sarcopenia is not only evident in mature muscle fibers but also in muscle resident satellite cells in which some functional parameters, at least for that concerns the $\mathrm{Ca}(2+)$ homeostasis, seem to be modified. It has been reported an age-dependent increase of lipid peroxidation, in cultured myotubes (Beccafico et al. 2007).

These evidences suggest that altered balance of ROS production is a critical issue for the progression of the diseases and that pathological conditions in which oxidative stress is a common feature, such as aging and disuses, may not be simply an issue of living or dying, but rather an issue of functioning well versus functioning poorly (Barzilai and Bartke 2009).

\section{Conclusions}

All of these findings demonstrate that sarcopenia has a multi-factorial etiology, involving a great variety of structural, biochemical and physiological abnormalities. Moreover, with age, the systemic environment is less effective in maintaining the myogenic fate of muscle stem cells and, instead, facilitates conversion to a fibrogenic fate, while the myogenic stem cells may be more sensitive to their environment, thus amplifying this phenomenon. The modifications with aging in 
the secretome of the different cell types present at different phases of regeneration is probably then crucial, as is expression of relevant cell surface receptors, which can also change with age (e.g. IGF and IGF receptors). Thus, while stem cells represent an important determinant for tissue regeneration, a "qualified" environment is necessary to guarantee and achieve functional results. In this context, therapeutic applications of adult stem cells to aged or pathological tissue repair in the context of regenerative medicine will require an increased understanding of stem-cell biology, of the cross-talk between the different cell types involved and of the environment of the ageing or pathological tissue.

\section{Methods}

\section{Muscle biopsies}

Biopsies from vastus lateralis or glutaeus medius muscles were obtained from healthy patients who underwent elective orthopedic surgery, after informed consent. Based on age, the patients were divided in two experimental groups: young individuals $(n=3)$ of $30.3 \pm 1.8$ years old, and aged individuals, $(n=5)$ of $83.3 \pm 6.3$ years old. Biopsies were performed following the procedure described by Engel (1994).

For lifespan determination, p16 mRNA and Telomere length measurements, five young (age range 15-24 year-old), and 10 old subjects : five old sedentary (age range 72-80 year-old) and five old active (age range 68-79 year-old), classified by clinicians on the basis of their examination and of questionnaires on their lifestyle, were used.

Cell cultures

Satellite cell populations were isolated from muscle fragments obtained from biopsies of healthy subjects at various ages, as described in (Musaro and Barberi 2010). Briefly, the isolated muscles were dissociated both mechanically, by mincing them into a coarse slurry with scissors, and enzymatically, using two different solutions: collagenase/dispase (Roche) $1 \mathrm{mg} / \mathrm{ml}$ in CMF (calcium and magnesium free PBS) and subsequently collagenase type II (Sigma) $0.1 \mathrm{mg} /$ $\mathrm{ml}$ in PBS. The isolated cells were then filtered through a $40 \mu \mathrm{m}$ cell strainer and centrifuged at
1,200 $\mathrm{rpm}$ for $15 \mathrm{~min}$ to sediment the dissociated cells. The pellet was resuspended in growth medium (GM) (consisting of Dulbecco's modified Eagle's medium (DMEM) supplemented with $20 \%$ horse serum), and the suspension was plated on cell culture $35 \mathrm{~mm}$ diameter dishes. The mixed population of cells was then enriched for myoblasts, using the preplating technique (Musarò et al. 2010).

Cells were then grown on tissue culture plastic dishes coated with collagen from calf skin (Sigma) and cultured in DMEM supplemented with either $15 \%$ autologous serum (obtained from the same donor of muscle biopsies) or $15 \%$ heterologous serum (obtained from young donor), and with $50 \mu \mathrm{g} / \mathrm{ml}$ of gentamycin.

For lifespan determination, in order to maintain the cells in a proliferative state as much as possible, cells were cultivated in growth medium consisting of $1 \mathrm{vol}$ m199 medium/4 vol DMEM (Invitrogen) supplemented with $20 \%$ foetal calf serum (Invitrogen), and $50 \mu \mathrm{g} / \mathrm{ml}$ Gentamycin (Invitrogen). The myogenic purity of the populations was monitored by immunocytochemistry using desmin as a marker.

At 5-6 days, when myoblasts showed an elongated phenotype, the myogenic cells were induced to differentiate by reducing the percentage of serum (Differentiation Medium: DMEM supplemented with either $5 \%$ autologous serum or $5 \%$ heterologous serum, and with $50 \mu \mathrm{g} / \mathrm{ml}$ of gentamycin).

Serum was prepared by the immediate centrifugation method from both young and aged donors. The sera were heat-treated at $56{ }^{\circ} \mathrm{C}$ for $30 \mathrm{~min}$ before use.

Immunofluorescence analysis

Proliferating and differentiated satellite cells were fixed in $4 \%$ paraformaldehyde and processed as described (Musarò and Rosenthal 1999). The nuclei of plated cells were visualized using Hoechst staining. We used the following antibodies: a monoclonal MF20 antibody (Hybridoma Bank); a monoclonal antibody against Pax-7 (Hybridoma Bank); a monoclonal antibody against MyoD (Santa Cruz); a monoclonal antibody against desmin (sigma); a monoclonal antibody against Ki67 (Dako).

Cell proliferation analysis

Cell proliferation was determined by cell counting and BrdU incorporation. BrdU incorporation (for $3 \mathrm{~h}$ in 
cell culture) assay was performed according to the manufacturer's instructions (cell proliferation kitAmersham GE Healthcare).

\section{ELISA}

The human TNF-alpha ELISA assay was performed using Bender MedSystems GmbH (Vienna, Austria). Intra-and inter-assay variability are reportedly $6 \%$ and $9.3 \%$, respectively. Data were derived from biopsies of $n=12$ old females $(73.9 \pm 2.5$ years $)$, $n=17$ young females ( $22.1 \pm 2.8$ years), $n=15$ old males $(74.4 \pm 3.1)$ and $n=12$ young $(21.2 \pm 3.3)$ males.

RNA extraction, cDNA synthesis and quantitative real time RT-PCR

Total RNA from myoblasts was extracted using Total RNA Isolation-NucleoSpin RNA II (Macherey-Nagel), according to the manufactures' instructions. After cDNA was synthesized using Superscript III Reverse Transcriptase kit (Invitrogen) according to the manufactures' instructions. Relative quantification was performed by real time RT-PCR using Rotor gene Q 6000 system (QIAGEN)). In brief, the following primers for the targets genes were used: p53 F: $5^{\prime}-$ TCTGACTGTACCACCATCCACTA-3', R: 5'-CAA ACACGCACCTCAAAGC-3'; p21 F: 5'-TGGACCT GTCACTGTCTTGT-3', R: 5'-TCCTGTGGGCGGA TTAG-3'. Gapdh (primers: F: 5'-CATTGCCCTCA ACGACCACTTTGT-3', R: 5'-CATTGCCCTCAAC GACCACTTTGT-3') was chosen as housekeeping gene. Real time RT-PCR reactions were performed in duplicate in the same run, using MESA GREEN MasterMix Plus for SYBR Assay (Eurogentec). All reactions consisted of an initial denaturation step at $95{ }^{\circ} \mathrm{C}$ for $5 \mathrm{~min}$, followed by 45 cycles of $95{ }^{\circ} \mathrm{C}$ for $15 \mathrm{~s}$ and $60{ }^{\circ} \mathrm{C}$ for $60 \mathrm{~s}$. A referent sample (human lymphoblastoid cell lines) was used as internal calibrator in each run. The $\Delta \mathrm{C}_{\mathrm{t}}$ value was calculated by subtracting the $C_{t}$ value for housekeeping genes from the $\mathrm{C}_{\mathrm{t}}$ value for the target gene of the same sample. The $\Delta \Delta \mathrm{C}_{\mathrm{t}}$ was then calculated by subtracting the $\Delta \mathrm{C}_{\mathrm{t}}$ value of the control sample (human lymphoblastoid cell lines) from the $\Delta \mathrm{C}_{\mathrm{t}}$ value of myoblasts. Relative expression level was then determined by calculating $2^{-\Delta \Delta C t}$ (Pfaffl 2004). All the measurements were repeated twice and the mean of experiments was considered.

Telomere length determination

Genomic DNA was extracted from myoblasts and telomere length was measured by a qPCR based method as previously described by Mamchaoui et al. (Skeletal muscle 2011).

\section{Statistical analysis}

Results are shown as mean \pm S.D. unless otherwise stated. Student's $t$ test was used for comparison of the means among groups (myoblasts from young and old). The basic criteria for normality and homoscedasticity have been tested by the Shapiro-Francia and Bartlett's tests. When normality or homogeneity of variance were not verified, Kruskal-Wallis tests were computed to compare groups. All statistical analyses were performed using the software STATA v.9.0. (Stata Corp. Texas, USA).

\section{Western blot analysis}

Frozen muscle biopsies were lysed in TEAD buffer (Tris-HCl $20 \mathrm{mM} \mathrm{pH}$ 7.5, EDTA $1 \mathrm{mM}$, NaN3 $1 \mathrm{mM}$, DTT $1 \mathrm{mM}$ ) containing protease inhibitor cocktail (Sigma-Aldrich, St. Louis, MO, USA) and phosphatase Inhibitor Cocktail 2, (Sigma-Aldrich, St. Louis, MO, USA), homogenized using a motor-driven homogenizer and centrifuged at $25,000 \mathrm{~g}$ for $1 \mathrm{~h}$ at $4 \mathrm{C}$. The supernatant containing the total protein extract was quantified by Bradford's method. Tissue lysates were stored at $-80{ }^{\circ} \mathrm{C}$ until analysis. About $40 \mu \mathrm{g}$ of the total protein was separated in $12 \%$ SDS-polyacrilamide gel and transferred to a nitrocellulose membrane (Trans-Blot Transfer Medium, Bio Rad, Hercules, CA) and immunoblotted under standard conditions with primary antibodies, as follows: 1:500 rabbit monoclonal C22B4 anti-NF-kB p65 (Cell Signalling Technology, Millipore, Beverly MA USA), 1:500 rabbit monoclonal 93H1 Phospho-NF-kB p65 (Ser536) (Cell Signalling Technology, Millipore, Beverly MA USA), and 1:10,000 mouse monoclonal SAP.4G5 anti- $\tilde{\beta}$ tubulin (Sigma-Aldrich, St. Louis, MO, USA). Antimouse or anti-rabbit immunoglobulin G horseradish peroxidase secondary antibodies and an enhanced 
chemiluminescence detection kit were from Santa Cruz Biotechnology, CA, USA).

Acknowledgments Work in the authors' laboratories has been supported by Seventh Framework Programme-Myoage and partly by MIUR, Fondazione Roma, Fondation Thierry Latran, AFM (to AM, VM and GBB) and AFLD (to VM).

Open Access This article is distributed under the terms of the Creative Commons Attribution License which permits any use, distribution, and reproduction in any medium, provided the original author(s) and the source are credited.

\section{References}

Arnold L, Henry A, Poron F, Baba-Amer Y, van Rooijen N, Plonquet A, Gherardi RK, Chazaud B (2007) Inflammatory monocytes recruited after skeletal muscle injury switch into antiinflammatory macrophages to support myogenesis. J Exp Med 204:1057-1069

Asakura A, Seale P, Girgis-Gabardo A, Rudnicki MA (2002) Myogenic specification of side population cells in skeletal muscle. J Cell Biol 159:123-134

Barton-Davis ER, Shoturma DI, Musaro A, Rosenthal N, Sweeney HL (1998) Viral mediated expression of insulinlike growth factor I blocks the aging-related loss of skeletal muscle function. Proc Natl Acad Sci USA 95:15603-15607

Barzilai N, Bartke A (2009) Biological approaches to mechanistically understand the healthy life span extension achieved by calorie restriction and modulation of hormones. J Gerontol A Biol Sci Med Sci 64:187-191

Beauchamp JR, Morgan JE, Pagel CN, Partridge TA (1999) Dynamics of myoblast transplantation reveal a discrete minority of precursors with stem cell-like properties as the myogenic source. J Cell Biol 144:1113-1122

Beccafico S, Puglielli C, Pietrangelo T, Bellomo R, Fanò G, Fulle S (2007) Age-dependent effects on functional aspects in human satellite cells. Ann N Y Acad Sci 1100:345-352

Beccafico S, Riuzzi F, Puglielli C, Mancinelli R, Fulle S, Sorci G, Donato R (2011) Human muscle satellite cells show age-related differential expression of $\mathrm{S} 100 \mathrm{~B}$ protein and RAGE. Age (Dordr) 33:523-541

Bencze M, Negroni E, Vallese D, Yacoub-Youssef H, Chaouch S, Wolff A, Aamiri A, Di Santo JP, Chazaud B, ButlerBrowne G, Savino W, Mouly V, Riederer I (2012) Proinflammatory macrophages enhance the regenerative capacity of human myoblasts by modifying their kinetics of proliferation and differentiation. Mol Ther 20:21682179

Bigot A, Jacquemin V, Debacq-Chainiaux F, Butler-Browne GS, Toussaint O, Furling D, Mouly V (2008) Replicative aging down-regulates the myogenic regulatory factors in human myoblasts. Biol Cell 100:189-199

Bigot A, Klein AF, Gasnier E, Jacquemin V, Ravassard P, Butler-Browne G, Mouly V, Furling D (2009) Large CTG repeats trigger p16-dependent premature senescence in myotonic dystrophy type 1 muscle precursor cells. Am J Pathol 174:1435-1442

Brack AS, Rando TA (2007) Intrinsic changes and extrinsic influences of myogenic stem cell function during aging. Stem Cell Rev 3:226-237

Brack AS, Bildsoe H, Hughes SM (2005) Evidence that satellite cell decrement contributes to preferential decline in nuclear number from large fibres during murine age-related muscle atrophy. J Cell Sci 118:4813-4821

Brack AS, Conboy MJ, Roy S, Lee M, Kuo CJ, Keller C, Rando TA (2007) Increased Wnt signaling during aging alters muscle stem cell fate and increases fibrosis. Science 317:807-810

Buckingham M (2007) Skeletal muscle progenitor cells and the role of Pax genes. C R Biol 330:530-533

Carlson BM (1968) Regeneration of the completely excised gastrocnemius muscle in the frog and rat from minced muscle fragments. J Morphol 125:447-472

Carlson BM (1972) Organizational aspects of muscle regeneration. In: Banker B, Przybylski R, van der Meulen J, Victor M (eds) Amsterdam: Excerpta Medica, pp 13-45

Carlson BM (1973) The regeneration of skeletal muscle: a review. Am J Anat 137:119-150

Carlson BM (1995) Factors influencing the repair and adaptation of muscles in aged individuals: satellite cells and innervation. J Gerontol 50A:96-100

Carlson BM (2003) Muscle regeneration in amphibians and mammals: passing the torch. Dev Dyn 226:167-181

Carlson BM, Faulkner JA (1989) Muscle transplantation between young and old rats: age of host determines recovery. Am J Physiol 256:C1262-C1266

Carlson BM, Dedkov EI, Borisov AB, Faulkner JA (2001) Skeletal muscle regeneration in very old rats. J Gerontol A Biol Sci Med Sci 56:224-233

Carnac G, Ricaud S, Vernus B, Bonnieu A (2006) Myostatin: biology and clinical relevance. Mini Rev Med Chem 6:765-770

Carosio S, Berardinelli MG, Aucello M, Musarò A (2011) Impact of ageing on muscle cell regeneration. Ageing Res Rev 10:35-42

Cevenini E, Caruso C, Candore G, Capri M, Nuzzo D, Duro G, Rizzo C, Colonna-Romano G, Lio D, Di Carlo D, Palmas MG, Scurti M, Pini E, Franceschi C, Vasto S (2010) Agerelated inflammation: the contribution of different organs, tissues and systems. How to face it for therapeutic approaches. Curr Pharm Des 16:609-618

Chakkalakal JV, Jones KM, Basson MA, Brack AS (2012) The aged niche disrupts muscle stem cell quiescence. Nature 490:355-360

Chakravarthy MV, Davis BS, Booth FW (2000) IGF-I restores satellite cell proliferative potential in immobilized old skeletal muscle. J Appl Physiol 89:1365-1379

Chilosi M, Poletti V, Zamò A, Lestani M, Montagna L, Piccoli P, Pedron S, Bertaso M, Scarpa A, Murer B, Cancellieri A, Maestro R, Semenzato G, Dogliosi C (2003) Aberrant Wnt/ beta-catenin pathway activation in idiopathic pulmonary fibrosis. Am J Pathol 162:1495-1502

Collins CA, Zammit PS, Ruiz AP, Morgan JE, Partridge TA (2007) A population of myogenic stem cells that survives skeletal muscle aging. Stem Cells 25:885-894 
Conboy IM, Rando TA (2002) The regulation of Notch signaling controls satellite cell activation and cell fate determination in postnatal myogenesis. Dev Cell 3:397-409

Conboy IM, Conboy MJ, Smythe GM, Rando TA (2003) Notchmediated restoration of regenerative potential to aged muscle. Science 302:1575-1577

Conboy IM, Conboy MJ, Wagers AJ, Girma ER, Weissman IL, Rando TA (2005) Rejuvenation of aged progenitor cells by exposure to a young systemic environment. Nature 433:760-764

Crown AL, He XL, Holly JM, Lightman SL, Stewart CE (2000) Characterisation of the IGF system in a primary adult human skeletal muscle cell model, and comparison of the effects of insulin and IGF-I on protein metabolism. J Endocrinol 167:403-415

De Angelis L, Berghella L, Coletta M, Lattanzi L, Zanchi M, De Cusella Angelis MG, Ponzetto C, Cossu G (1999) Skeletal myogenic progenitors originating from embryonic dorsal aorta coexpress endothelial and myogenic markers and contribute to postnatal muscle growth and regeneration. J Cell Biol 147:869-878

Decary S, Mouly V, Hamida CB, Sautet A, Barbet JP, ButlerBrowne GS (1997) Replicative potential and telomere length in human skeletal muscle: implications for satellite cell-mediated gene therapy. Hum Gene Ther 8:1429-1438

Decary S, Hamida CB, Mouly V, Barbet JP, Hentati F, ButlerBrowne GS (2000) Shorter telomeres in dystrophic muscle consistent with extensive regeneration in young children. Neuromuscul Disord 10:113-120

Di Donna S, Mamchaoui K, Cooper RN, Seigneurin-Venin S, Tremblay J, Butler-Browne GS, Mouly V (2003) Telomerase can extend the proliferative capacity of human myoblasts, but does not lead to their immortalization. Mol Cancer Res 1:643-653

Dobrowolny G, Aucello M, Rizzuto E, Beccafico S, Mammucari C, Boncompagni S, Belia S, Wannenes F, Nicoletti C, Del Prete Z, Rosenthal N, Molinaro M, Protasi F, Fanò G, Sandri M, Musarò A (2008) Skeletal muscle is a primary target of SOD1G93A-mediated toxicity. Cell Metab $8: 425-436$

Dominique JE, Gerard C (2006) Myostatin regulation of muscle development: Molecular basis, natural mutations, physiopathological aspects. Exp Cell Res 312:2401-2414

Douillard-Guilloux G, Mouly V, Caillaud C, Richard E (2009) Immortalization of murine muscle cells from lysosomal alpha-glucosidase deficient mice: a new tool to study pathophysiology and assess therapeutic strategies for Pompe disease. Biochem Biophys Res Commun 388:333-338

Edstrom E, Ulfhake B (2005) Sarcopenia is not due to lack of regenerative drive in senescent skeletal muscle. Aging Cell 4:65-77

Engel AG (1994) The muscle biopsy. In: Engel AG, FranziniArmstrong E (eds) Myology, 2nd edn. McGraw-Hill, New York, pp 822-831

Esposito LA, Melov S, Panov A, Cottrell BA, Wallace DC (1999) Mitochondrial disease in mouse results in increased oxidative stress. Proc Natl Acad Sci USA. 96:4820-4825

Esposito LA, Kokoszka JE, Waymire KG, Cottrell B, MacGregor GR, Wallace DC (2000) Mitochondrial oxidative stress in mice lacking the glutathione peroxidase-1 gene. Free Radic Biol Med 28:754-766

Ferrari G, Stornaiuolo A, Mavilio F (2001) Failure to correct murine muscular dystrophy. Nature 411:1014-1015

Foulstone EJ, Savage PB, Crown AL, Holly JM, Stewart CE (2003a) Adaptations of the IGF system during malignancy: human skeletal muscle versus the systemic environment. Horm Metab Res 35:667-674

Foulstone EJ, Savage PB, Crown AL, Holly JM, Stewart CE (2003b) Role of insulin-like growth factor binding protein3 (IGFBP-3) in the differentiation of primary human adult skeletal myoblasts. J Cell Physiol 195:70-79

Foulstone EJ, Huser C, Crown AL, Holly JM, Stewart CE (2004) Differential signalling mechanisms predisposing primary human skeletal muscle cells to altered proliferation and differentiation: roles of IGF-I and TNFalpha. Exp Cell Res 294:223-235

Fulle S, Di Donna S, Puglielli C, Pietrangelo T, Beccafico S, Bellomo R, Protasi F, Fanò G (2005) Age-dependent imbalance of the antioxidative system in human satellite cells. Exp Gerontol 40:189-190

Fulle S, Centurione L, Mancinelli R, Sancilio S, Manzoli FA, Di Pietro R (2012) Stem cell ageing and apoptosis. Curr Pharm Des 18:1694-1717

Gibson MC, Schultz E (1983) Age-related differences in absolute numbers of skeletal muscle satellite cells. Muscle Nerve 6:574-580

Goetsch SC, Hawke TJ, Gallardo TD, Richardson JA, Garry DJ (2003) Transcriptional profiling and regulation of the extracellular matrix during muscle regeneration. Physiol Genomics 14:261-271

Grounds MD (2002) Reasons for the degeneration of ageing skeletal muscle: a central role for IGF-1 signalling. Biogerontology 3:19-24

Grounds MD, McGeachie JK (1987) Reutilisation of tritiated thymidine in studies of regenerating skeletal muscle. Cell Tissue Res 250:141-148

Guo K, Wang J, Andrés V, Smith RC, Walsh K (1995) MyoDinduced expression of $\mathrm{p} 21$ inhibits cyclin-dependent kinase activity upon myocyte terminal differentiation. Mol Cell Biol 15:3823-3829

Gussoni E, Soneoka Y, Strickland CD, Buzney EA, Khan MK, Flint AF, Kunkel LM, Mulligan RC (1999) Dystrophin expression in the mdx mouse restored by stem cell transplantation. Nature 401:390-394

Halevy O, Novitch BG, Spicer DB, Skapek SX, Rhee J, Hannon GJ, Beach D, Lassar AB (1995) Correlation of terminal cell cycle arrest of skeletal muscle with induction of p21 by MyoD. Science 267:1018-1021

Harman D (1956) Aging: a theory based on free radical and radiation chemistry. J Gerontol 11:298-300

Hawke TJ, Garry DJ (2001) Myogenic satellite cells: physiology to molecular biology. J Appl Physiol 91:534-551

Jacquemin V, Furling D, Bigot A, Butler-Browne GS, Mouly V (2004) IGF-1 induces human myotube hypertrophy by increasing cell recruitment. Exp Cell Res 299:148-158

Jacquemin V, Butler-Browne GS, Furling D, Mouly V (2007) IL-13 mediates the recruitment of reserve cells for fusion during IGF-1-induced hypertrophy of human myotubes. J Cell Sci 120:670-681 
Jang YC, Van Remmen H (2011) Age-associated alterations of the neuromuscular junction. Exp Gerontol 46:193-198

Jang YC, Lustgarten MS, Liu Y, Muller FL, Bhattacharya A, Liang H, Salmon AB, Brooks SV, Larkin L, Hayworth CR, Richardson A, Van Remmen H (2010) Increased superoxide in vivo accelerates age-associated muscle atrophy through mitochondrial dysfunction and neuromuscular junction degeneration. FASEB J. 24:1376-1390

Jespersen J, Kjaer M, Schjerling P (2006) The possible role of myostatin in skeletal muscle atrophy and cachexia. Scand J Med Sci Sports 16:74-82

Jiang F, Parsons CJ, Stefanovic B (2006) Gene expression profile of quiescent and activated rat hepatic stellate cells implicates Wnt signaling pathway in activation. J Hepatol 45:401-409

Kadi F, Eriksson A, Holmner S, Butler-Browne GS, Thornell LE (1999) Cellular adaptation of the trapezius muscle in strength-trained athletes. Histochem Cell Biol 111:189-195

Kadi F, Charifi N, Denis C, Lexell J (2004) Satellite cells and myonuclei in young and elderly women and men. Muscle Nerve 29:120-127

Kambadur R, Sharma M, Smith TPL, Bass JJ (1997) Mutations in myostatin (GDF8) in double-muscled belgian blue and piedmontese cattle. Genome Res 7:910-915

Karpati G, Molnar MJ (2008) Muscle fibre regeneration in human skeletal muscle diseases. In: Schiaffino S, Partridge $\mathrm{T}$ (eds) Skeletal Muscle Repair and Regeneration. (Advances in Muscle Research). Springer Verlag, The Netherlands, pp 45-64

Kim JS, Kosek DJ, Petrella JK, Cross JM, Bamman MM (2005) Resting and load-induced levels of myogenic gene transcripts differ between older adults with demonstrable sarcopenia and young men and women. J Appl Physiol 99:2149-2158

Kosek DJ, Kim JS, Petrella JK, Cross JM, Bamman MM (2006) Efficacy of 3 days/wk resistance training on myofiber hypertrophy and myogenic mechanisms in young vs. older adults. J Appl Physiol 101:531-544

Kovacheva EL, Hikim AP, Shen R, Sinha I, Sinha-Hikim I (2010) Testosterone supplementation reverses sarcopenia in aging through regulation of myostatin, c-Jun NH2-terminal kinase, Notch, and Akt signaling pathways. Endocrinology 151:628-638

Krippendorf BB, Riley DA (1993) Distinguishing unloadingversus reloading-induced changes in rat soleus muscle. Muscle Nerve 16:99-108

Kuang S, Chargé SB, Seale P, Huh M, Rudnicki MA (2006) Distinct roles for $\mathrm{Pax} 7$ and $\mathrm{Pax} 3$ in adult regenerative myogenesis. J Cell Biol 172:103-113

Kuang S, Kuroda K, Le Grand F, Rudnicki MA (2007) Asymmetric self-renewal and commitment of satellite stem cells in muscle. Cell 129:999-1010

Larsson L (1982) Physical training effects on muscle morphology in sedentary males at different ages. Med Sci Sports Exerc 14:203-2066

Larsson L, Ansved T (1995) Effects of ageing on the motor unit. Prog Neurobiol 45:397-458

Le Bihan MC, Bigot A, Jensen SS, Dennis JL, RogowskaWrzesinska A, Lainé J, Gache V, Furling D, Jensen ON, Voit T, Mouly V, Coulton GR, Butler-Browne G (2012) In- depth analysis of the secretome identifies three major independent secretory pathways in differentiating human myoblasts. J Proteomics 77:344-356

Lebovitz RM, Zhang H, Vogel H, Cartwright J Jr, Dionne L, Lu N, Huang S, Matzuk MM (1996) Neurodegeneration, myocardial injury, and perinatal death in mitochondrial superoxide dismutase-deficient mice. Proc Natl Acad Sci U S A 93:9782-9787

Lee S, Shin HS, Shireman PK, Vasilaki A, Van Remmen H, Csete ME (2006) Glutathione-peroxidase-1 null muscle progenitor cells are globally defective. Free Radic Biol Med 41:1174-1184

Li H, Grenet J, Kidd VJ (1995) Structure and gene expression of avian cyclin D2. Gene 167:341-342

Mackey AL, Esmarck B, Kadi F, Koskinen SO, Kongsgaard M, Sylvestersen A, Hansen JJ, Larsen G, Kjaer M (2007) Enhanced satellite cell proliferation with resistance training in elderly men and women. Scand J Med Sci Sports 17:34-42

Mamchaoui K, Trollet C, Bigot A, Negroni E, Chaouch S, Wolff A, Kandalla PK, Marie S, Di Santo J, St Guily JL, Muntoni F, Kim J, Philippi S, Spuler S, Levy N, Blumen SC, Voit T, Wright WE, Aamiri A, Butler-Browne G, Mouly V (2011) Immortalized pathological human myoblasts: towards a universal tool for the study of neuromuscular disorders. Skelet Muscle 1:34

Mantovani A, Sica A, Sozzani S, Allavena P, Vecchi A, Locati M (2004) The chemokine system in diverse forms of macrophage activation and polarization. Trends Immunol 25:677-686

Marshall PA, Williams PE, Goldspink G (1989) Accumulation of collagen and altered fiber-type ratios as indicators of abnormal muscle gene expression in the mdx dystrophic mouse. Muscle Nerve 12:528-537

Martin I, Jones MA, Rhodenizer D, Zheng J, Warrick JM, Seroude L, Grotewiel M (2009) Sod2 knockdown in the musculature has whole organism consequences in Drosophila. Free Radic Biol Med 47:803-813

Marzetti E, Wohlgemuth SE, Lees HA, Chung HY, Giovannini S, Leeuwenburgh C (2008) Age-related activation of mitochondrial caspase-independent apoptotic signaling in rat gastrocnemius muscle. Mech Ageing Dev 129:542-549

Marzetti E, Calvani R, Bernabei R, Leeuwenburgh C (2012) Apoptosis in skeletal myocytes: a potential target for interventions against sarcopenia and physical frailty-a mini-review. Gerontology 58:99-106

Mauro A (1961) Satellite cell of skeletal muscle fibers. J Biophys Biochem Cytol 9:493-495

McGeachie JK, Grounds MD (1995) Retarded myogenic cell replication in regenerating skeletal muscles of old mice: an autoradiographic study in young and old BALBc and SJL/J mice. Cell Tissue Res 280:277-282

McPherron AC, Lawler AM, Lee SJ (1997) Regulation of skeletal muscle mass in mice by a new TGF-beta superfamily member. Nature 387:83-90

Mendias CL, Marcin JE, Calerdon DR, Faulkner JA (2006) Contractile properties of EDL and soleus muscles of myostatin-deficient mice. J Appl Physiol 101:898-905

Mendias CL, Bakhurin KI, Faulkner JA (2008) Tendons of myostatin-deficient mice are small, brittle, and hypocellular. Proc Natl Acad Sci U S A 105:388-393 
Mendias CL, Kayupov E, Bradley JR, Brooks SV, Claflin DR (2011) Decreased specific force and power production of muscle fibers from myostatin-deficient mice are associated with a suppression of protein degradation. J Appl Physiol 111:185-191

Moss FP, Leblond CP (1971) Satellite cells as the source of nuclei in muscles of growing rats. Anat Rec 170:421-435

Muller FL, Song W, Liu Y, Chaudhuri A, Pieke-Dahl S, Strong R, Huang TT, Epstein CJ, Roberts LJ II, Csete M, Faulkner JA, Van Remmen H (2006) Absence of CuZn superoxide dismutase leads to elevated oxidative stress and acceleration of age-dependent skeletal muscle atrophy. Free Radic Biol Med 40:1993-2004

Musarò A, Barberi L (2010) Isolation and culture of mouse satellite cells. Methods Mol Biol 633:101-111

Musarò A, Rosenthal N (1999) Maturation of the myogenic program is induced by postmitotic expression of insulinlike growth factor I. Mol Cell Biol 19:3115-3124

Musaro A, Cusella De Angelis MG, Germani A, Ciccarelli C, Molinaro M, Zani BM (1995) Enhanced expression of myogenic regulatory genes in aging skeletal muscle. Exp Cell Res 221:241-248

Musarò A, McCullagh KJ, Naya FJ, Olson EN, Rosenthal N (1999) IGF-1 induces skeletal myocyte hypertrophy through calcineurin in association with GATA-2 and NFATc1. Nature 400:581-585

Musarò A, McCullagh K, Paul A, Houghton L, Dobrowolny G, Molinaro M, Barton ER, Sweeney HL, Rosenthal N (2001) Localized Igf-1 transgene expression sustains hypertrophy and regeneration in senescent skeletal muscle. Nat Genet 27:195-200

Musarò A, Giacinti C, Borsellino G, Dobrowolny G, Pelosi L, Cairns L, Ottolenghi S, Cossu G, Bernardi G, Battistini L, Molinaro M, Rosenthal N (2004) Stem cell-mediated muscle regeneration is enhanced by local isoform of insulin-like growth factor 1. Proc Natl Acad Sci USA 101:1206-1210

Musarò A, Fulle S, Fanò G (2010) Oxidative stress and muscle homeostasis. Curr Opin Clin Nutr Metab Care 13:236-242

Nguyen HX, Tidball JG (2003) Interactions between neutrophils and macrophages promote macrophage killing of rat muscle cells in vitro. J Physiol 547:125-132

Oberc MA, Engel WK (1977) Ultrastructural localization of calcium in normal and abnormal skeletal muscle. Lab Invest 36:566-577

Olsen S, Aagaard P, Kadi F, Tufekovic G, Verney J, Olesen JL, Suetta C, Kjaer M (2006) Creatine supplementation augments the increase in satellite cell and myonuclei number in human skeletal muscle induced by strength training. J Physiol 573:525-534

Paliwal P, Pishesha N, Wijaya D, Conboy IM (2012) Age dependent increase in the levels of osteopontin inhibits skeletal muscle regeneration. Aging (Albany NY) 4:553-566

Partridge TA (2004) Stem cell therapies for neuromuscular diseases. Acta Neurol Belg 104:141-147

Pelosi L, Giacinti C, Nardis C, Borsellino G, Rizzuto E, Nicoletti C, Wannenes F, Battistini L, Rosenthal N, Molinaro M, Musarò A (2007) Local expression of IGF-1 accelerates muscle regeneration by rapidly modulating inflammatory cytokines and chemokines. FASEB J 21:1393-1402
Personius KE, Jayaram A, Krull D, Brown R, Xu T, Han B, Burgess K, Storey C, Shah B, Tawil R, Welle S (2010) Grip force, EDL contractile properties, and voluntary wheel running after postdevelopmental myostatin depletion in mice. J Appl Physiol 109:886-894

Pfaffl MW (2004) Quantification strategies in real-time PCR. In: Bustin SA (ed) A-Z of Quantitative PCR. IUL Biotechnology Series, International University Line, La Jolla, CA, pp 87-120

Phillips T, Leeuwenburgh C (2005) Muscle fiber specific apoptosis and TNF-alpha signalling in sarcopenia are attenuated by life-long calorie restriction. FASEB J 19:668-670

Ploquin C, Chabi B, Fouret G, Vernus B, Feillet-Coudray C, Coudray C, Bonnieu A, Ramonatxo C (2012) Lack of myostatin alters intermyofibrillar mitochondria activity, unbalances redox status, and impairs tolerance to chronic repetitive contractions in muscle. Am J Physiol Endocrinol Metab 302:1000-1008

Polesskaya A, Seale P, Rudnicki MA (2003) Wnt signaling induces the myogenic specification of resident $\mathrm{CD} 45+\mathrm{a}-$ dult stem cells during muscle regeneration. Cell 113:841-852

Raue U, Slivka D, Jemiolo B, Hollon C, Trappe S (2006) Myogenic gene expression at rest and after a bout of resistance exercise in young (18-30 yr) and old (80-89 yr) women. J Appl Physiol 101:53-59

Reisz-Porszasz S, Bhasin S, Artaza JN, Shen R, Sinha-Hikim I, Hogue A, Fielder TJ, Gonzalez-Cadavid NF (2003) Lower skeletal muscle mass in male transgenic mice with musclespecific overexpression of myostatin. Am J Physiol Endocrinol Metab 285:876-888

Renault V, Piron-Hamelin G, Forestier C, DiDonna S, Decary S, Hentati F, Saillant G, Butler-Browne GS, Mouly V (2000) Skeletal muscle regeneration and the mitotic clock. Exp Gerontol 35:711-719

Renault V, Thornell LE, Eriksson PO, Butler-Browne G, Mouly V (2002) Regenerative potential of human skeletal muscle during aging. Aging Cell 1:132-139

Reynaud EG, Leibovitch MP, Tintignac LA, Pelpel K, Guillier M, Leibovitch SA (2000) Stabilization of MyoD by direct binding to p57(Kip2). J Biol Chem 275:18767-18776

Riederer I, Negroni E, Bencze M, Wolff A, Aamiri A, Di Santo JP, Silva-Barbosa SD, Butler-Browne G, Savino W, Mouly V (2012) Slowing down differentiation of engrafted human myoblasts into immunodeficient mice correlates with increased proliferation and migration. Mol Ther 20:146-154

Roth SM, Martel GF, Ivey FM, Lemmer JT, Tracy BL, Metter EJ, Hurley BF, Rogers MA (2001) Skeletal muscle satellite cell characteristics in young and older men and women after heavy resistance strength training. J Gerontol A Biol Sci Med Sci 56:240-247

Sajko S, Kubinova L, Cvetko E, Kreft M, Wernig A, Erzen I (2004) Frequency of M-cadherin-stained satellite cells declines in human muscles during aging. J Histochem Cytochem 52:179-185

Sandri M, Barberi L, Bijlsma AY, Blaauw B, Dyar KA, Milan G, Mammucari C, Meskers CGM, Pallafacchina G, Paoli A, Pion D, Roceri M, Romanello V, Serrano AL, L. Toniolo, Larsson L, Maier AB, Muñoz-Cánoves P, Musarò A, 
Pende M, Reggiani C, Rizzuto R, Schiaffino S (2013) Signalling pathways regulating muscle mass in ageing skeletal muscle. The role of the IGF1-Akt-mTOR-FoxO pathway. Biogerontology (this isssue)

Schirwis E, Agbulut O, Vadrot N, Mouisel E, Hourdé C, Bonnieu A, Butler-Browne G, Amthor H, Ferry A (2012) The beneficial effect of myostatin deficiency on maximal muscle force and power is attenuated with age. Exp Gerontol 48:183-190

Schuelke M, Wagner KR, Stolz LE, Hubner C, Riebel T, Komen W, Braun T, Tobin JF, Lee SJ (2004) Myostatin mutation associated with gross muscle hypertrophy in a child. N Engl J Med 350:2682-2688

Schultz E (1996) Satellite cell proliferative compartments in growing skeletal muscles. Dev Biol 175:84-94

Schultz E, Lipton BH (1982) Skeletal muscle satellite cells: changes in proliferation potential as a function of age. Mech Ageing Dev 20:377-383

Schwarzkopf M, Coletti D, Marazzi G, Sassoon D (2008) Chronic p53 activity leads to skeletal muscle atrophy and muscle stem cell perturbation. Basic Applied Myology 18:131-138

Scicchitano BM, Rizzuto E, Musarò A (2009) Counteracting muscle wasting in aging and neuromuscular diseases: the critical role of IGF-1. Aging 5:1-7

Shavlakadze T, Winn N, Rosenthal N, Grounds MD (2005) Reconciling data from transgenic mice that overexpress IGF-I specifically in skeletal muscle. Growth Horm IGF Res 15:4-18

Shefer G, Van de Mark DP, Richardson JB, Yablonka-Reuveni Z (2006) Satellite-cell pool size does matter: defining the myogenic potency of aging skeletal muscle. Dev Biol 294:50-66

Sinha-Hikim I, Sinha-Hikim AP, Parveen M, Shen R, Goswami R, Tran P, Crum A, Norris KC (2013) Long-Term Supplementation With a Cystine-Based Antioxidant Delays Loss of Muscle Mass in Aging. J Gerontol A Biol Sci Med Sci (in press)

Skuk D, Tremblay JP (2003) Myoblast transplantation: the current status of a potential therapeutic tool for myopathies. J Muscle Res Cell Motil 24:285-300

Snijders T, Verdijk LB, van Loon LJ (2009) The impact of sarcopenia and exercise training on skeletal muscle satellite cells. Ageing Res Rev 8:328-338

Snow MH (1977) The effects of aging on satellite cells in skeletal muscles of mice and rats. Cell Tissue Res 185:399-408

Sohal RS, Weindruch R (1996) Oxidative stress, caloric restriction, and aging. Science 273:59-63

St. Pierre BA, Tidball JG (1994) Differential response of macrophage subpopulations to soleus muscle reloading following rat hindlimb suspension. J Appl Physiol 77:290-297

Stewart CE, Newcomb PV, Holly JM (2004) Multifaceted roles of TNF-alpha in myoblast destruction: a multitude of signal transduction pathways. J Cell Physiol 198:237-247

Tajbakhsh S (2009) Skeletal muscle stem cells in developmental versus regenerative myogenesis. $J$ Intern Med 266:372-389

Tamaki T, Akatsuka A, Ando K, Nakamura Y, Matsuzawa H, Hotta T, Roy RR, Edgerton VR (2002) Identification of myogenic-endothelial progenitor cells in the interstitial spaces of skeletal muscle. J Cell Biol 157:571-577

Tidball JG, Villalta SA (2010) Regulatory interactions between muscle and the immune system during muscle regeneration. Am J Physiol Regul Integr Comp Physiol 298:1173-1187

Tidball JG, Wehling-Henricks M (2007) Macrophages promote muscle membrane repair and muscle fibre growth and regeneration during modified muscle loading in mice in vivo. J Physiol 578:327-336

Turpin SM, Lancaster GI, Darby I, Febbraio MA, Watt MJ (2006) Apoptosis in skeletal muscle myotubes is induced by ceramides and is positively related to insulin resistance. Am J Physiol Endocrinol Metab 291:1341-1350

Van Remmen H, Ikeno Y, Hamilton M, Pahlavani M, Wolf N, Thorpe SR, Alderson NL, Baynes JW, Epstein CJ, Huang TT, Nelson J, Strong R, Richardson A (2003) Life-long reduction in MnSOD activity results in increased DNA damage and higher incidence of cancer but does not accelerate aging. Physiol Genomics 16:29-37

Vasyutina E, Lenhard DC, Birchmeie C (2007) Notch function in myogenesis. Cell Cycle 6:1451-1454

Verdijk LB, Koopman R, Schaart G, Meijer K, Savelberg HH, van Loon LJ (2007) Satellite cell content is specifically reduced in type II skeletal muscle fibers in the elderly. Am J Physiol Endocrinol Metab 292:151-157

Verdijk LB, Gleeson BG, Jonkers RA, Meijer K, Savelberg HH, Dendale P, van Loon LJ (2009) Skeletal muscle hypertrophy following resistance training is accompanied by a fiber type-specific increase in satellite cell content in elderly men. J Gerontol A Biol Sci Med Sci 64:332-339

Verney J, Kadi F, Charifi N, Feasson L, Saafi MA, Castells J, Piehl-Aulin K, Denis C (2008) Effects of combined lower body endurance and upper body resistance training on the satellite cell pool in elderly subjects. Muscle Nerve 38:1147-1154

Wagner KR (2005) Muscle regeneration through myostatin inhibition. Curr Opin Rheumatol 17:720-724

Walker DK, Fry CS, Drummond MJ, Dickinson JM, Timmerman KL, Gundermann DM, Jennings K, Volpi E, Rasmussen BB (2012) PAX7 + satellite cells in young and older adults following resistance exercise. Muscle Nerve 46:51-59

Williams MD, Van Remmen H, Conrad CC, Huang TT, Epstein CJ, Richardson A (1998) Increased oxidative damage is correlated to altered mitochondrial function in heterozygous manganese superoxide dismutase knockout mice. J Biol Chem 273:28510-28515

Yablonka-Reuveni Z, Seger R, Rivera AJ (1999) Fibroblast growth factor promotes recruitment of skeletal muscle satellite cells in young and old rats. J Histochem Cytochem 47:23-42

Yin H, Price F, Rudnicki MA (2013) Satellite cells and the muscle stem cell niche. Physiol Rev 93:23-67

Zammit PS (2008) The Muscle Satellite Cell: The Story of a Cell on the Edge. In: Schiaffino S, Partridge T (eds) Skeletal Muscle Repair and Regeneration. (Advances in Muscle Research). Springer Verlag, The Netherlands, pp 45-64

Zammit PS, Heslop L, Hudon V, Rosenblatt JD, Tajbakhsh S, Buckingham ME, Beauchamp JR, Partridge TA (2002) Kinetics of myoblast proliferation show that resident satellite cells are competent to fully regenerate skeletal muscle fibers. Exp Cell Res 281:39-49 
Zhang Y, Ikeno Y, Qi W, Chaudhuri A, Li Y, Bokov A, Thorpe SR, Baynes JW, Epstein C, Richardson A, Van Remmen H (2009) Mice deficient in both Mn Superoxide Dismutase and Glutathione Peroxidase-1 have increased oxidative damage and a greater incidence of pathology but no reduction in longevity. J Gerontol A Biol Sci Med Sci 64:1212-1220
Zhu CH, Mouly V, Cooper RN, Mamchaoui K, Bigot A, Shay JW, Di Santo JP, Butler-Browne GS, Wright WE (2007) Cellular senescence in human myoblasts is overcome by human telomerase reverse transcriptase and cyclin-dependent kinase 4: consequences in aging muscle and therapeutic strategies for muscular dystrophies. Aging Cell 6:515-523 